\title{
THE PROCESS SIMULATION OF NATURAL GAS STEAM REFORMING IN AN INTEGRATED MEMBRANE REACTOR
}

\author{
Grazia Leonzio \\ Department of Industrial and Information Engineering and Economics, University of L'Aquila, Via Giovanni Gronchi \\ 18, 67100 L'Aquila, Italy
}

\begin{abstract}
Natural gas steam reforming due to the abundant availability of natural gas is the principal way to produce hydrogen. Higher purity of hydrogen can be obtained with membrane reactor. An integrated membrane reactor that useNi(10)/CeLaZr catalyst supported on SSiC ceramic foam is analyzed in this research. Respect to other literature works, foam catalyst is used in place of common pellet catalyst to have better performance of the process with higher distribution of temperature. A rating mode is carried out founding the correct heat transfer coefficient of the reactor. A modeling of the reactor is carried out in Aspen Plus using the correlation presented in literature for the catalyst foam, Sieverts' law and Numaguchi kinetic. The commonly used Xu and Froment kinetic is replaced by Numaguchi kinetic. Results on reactor performance show satisfactory agreement with experimental data. A study of methane conversion, hydrogen recovery, temperature of reactor, hydrogen partial pressure versus reactor length and membrane permeability is performed. The membrane permeability has positive effect on methane conversion and hydrogen recovery. For the other parameters the effect is negative. Future works should optimize the operation of the integrated membrane reactor to have the higher hydrogen production and methane conversion.
\end{abstract}

Keywords: Natural Gas Steam Reforming, Integrated Membrane Reactor, Process Simulation, Hydrogen Production, Kinetic Reaction, Catalyst On Foam.

\section{INTRODUCTION}

Today natural gas, consisting of up to $95 \%$ methane, is a high quality energy and chemical raw material used in alternative to petroleum for the production of energy, fuels and chemical commodities [1]. A technique to add a high value to natural gas is the steam reforming reaction, used to produce hydrogen, the most significant energy carrier and source of the future. Globally, about 50 million tons of hydrogen (about the $80-85 \%$ of world's hydrogen) is produced via steam reforming while other methods use coal gasification or are from renewable sources as biomass, water electrolysis or bio-ethanol for the next future [3]. Among all methods natural gas steam reforming or known as methane steam reforming is the cheapest and economically competitive method to produce $\mathrm{H}_{2}$ on a commercial scale [4]. Various efforts are carried out to assess the economic aspects and environmental impact of the hydrogen production. Hydrogen is used as a raw material in a range of chemical, petrochemical and metallurgical processes, for the production of ammonia, methanol and other chemical; it is used in the Fischer Tropsch synthesis, in the fuel cells, fuel cell vehicles, internal combustion engines vehicles and can store energy by water electrolysis. Hydrogen is an alternative to clean energy. Infect, due to economic and environmental benefits, hydrogen can be used in the future as an energy source and from environmental prospective is the most promising solution to reduce the emissions.

The use of membrane reactors to produce high purity hydrogen has more attention in the recent years, infect the simultaneous presence of reaction and separation determines lower cost(capital and downstream separation costs)respect to conventional reactors. In addition, conversion and selectivity of the reaction are better, so a membrane reactor can produce hydrogen whit high efficiency.

Hydrogen is separated from the reaction side, shifting the equilibrium of the reaction towards the hydrogen formation and increasing the methane conversion at lower temperatures [5]. In general, the reactions take place at high temperatures $(>1073 \mathrm{~K})$, but higher methane conversion can be obtained using membrane reactor at lower temperatures (less than $823 \mathrm{~K}$ ). Then, the removal of products increases the residence time of the reactor and drives the equilibrium toward the completion [6]. Hydrogen is carried away from the reaction zone using a sweep gas, commonly a stream of $\mathrm{H}_{2} \mathrm{O}, \mathrm{N}_{2}, \mathrm{He}$ or $\mathrm{O}_{2}[2]$.

Several works are reported in literature about the use of membrane reactors to produce hydrogen by steam reforming $[7,8]$ : the most of them are at elevated temperature $(>723$ $\mathrm{K})[9,10]$, while only few experimental works are at lower temperature as $623 \mathrm{~K}[11,12]$.

Different configurations of membrane reactors, with embedded or external membrane[13] or with open architecture [14] are described. In other cases, molten salts are used as heat transfer fluid using solar energy and improving the thermal efficiency of the process[14, 15]: it is an environmentally system that produces $\mathrm{H}_{2}$, reduces $\mathrm{CO}_{2}$ emissions, and saves the otherwise combusted fraction of $\mathrm{CH}_{4}[16,17]$. Infect, natural gas steam reforming reaction, for hydrogen production is strongly endothermic, hence, requires a large amount of reaction heat. 
Different types of materials can be used for membranes in the hydrogen separation:polymeric membranes, porous membranes, dense metal membranes and proton conducting membranes. The most important parameters comparing membranes are: perm-selectivity, the flux and the temperature range at which the membrane can be applied.

Dense metal and ceramic membranes (mainly palladium alloys) are currently the most used materials due to the high selectivity to produce hydrogen whit high purity. $\mathrm{Pd}$-alloys are used to decrease the embrittlement and poisoning (due to $\mathrm{H}_{2} \mathrm{~S}$ and CO) problems[18, 19]. Several researches are carried out to study the separation characteristics of $\mathrm{Pd}$ membranes: palladium membrane has high permeability and selectivity to hydrogen $[20,21]$.

Extensive experimental studies and DFT-based calculations shows that the permeability and the stability against poisoning can be improved using $\mathrm{Pd}$ in binary or ternary alloys [22, 23]: among different additives (such as $\mathrm{Ni}, \mathrm{Au}$, $\mathrm{Ag}, \mathrm{Rh}, \mathrm{Pt}$ ) $\mathrm{Au}$ or Ag can increase the permeability of about 5 times: the selectivity is reported to be $>10^{3}$ [24]. The permeation of hydrogen through the membrane is described by the Sieverts' law. The selectivity can be improved in composite membranes that consist of a thin membrane layer deposited into a porous support via electrodes plating or sputtering: the permeability and selectivity depend on the coverage of the support pores by the membrane layer [25, $26,27]$. In this membranes, higher hydrogen permeability, increased mechanical resistance, lower cost respect to unsupported membranes are achieved as described by Anzelmo et al. [28], describing also the effect of different parameters as reactor pressure and permeate sweep gas rate on methane conversion, hydrogen recovery and hydrogen permeate purity.

The reaction system to produce hydrogen uses catalysts that show high activity at such low temperatures and decrease the formation of the coke. The selection of catalyst is important for the process and should be considered from catalytic and economic aspect. Ni-based catalysts are the most common used catalysts due to their high activity and low costs, however Ni can promote carbon deposition on catalyst surface [29]. CO,Fe and noble metals, such as Rh, $\mathrm{Pd}$, Ir, Pt and Ru are also used as catalysts being more active and more resistance to coke deposition compared to nonnoble metals $[30,31,32,33]$. $\mathrm{Ru}$ instead of $\mathrm{Ni}$, can maximize the performance of a membrane reactor due to the high activity and low costs compared to other noble metals, so it is a potential choice $[34,35,36]$. Various supports as $\mathrm{Al}_{2} \mathrm{O}_{3}, \mathrm{TiO}_{2}, \mathrm{CeO}_{2}, \mathrm{ZrO}_{2}, \mathrm{La}_{2} \mathrm{O}_{3}, \mathrm{CeO}_{2}-\mathrm{ZrO}_{2}$, zeolites, phyrochlore are used for $\mathrm{Ru}$ catalyst. However, the application of noble metals is limited due to their high price and unavailability.

Catalytic support materials also have significant effects on catalyst performances: the widely used pellet supports show low thermal dispersion because due to low thermal conductivity. Cold or hot spots are formed on the catalyst surface during reforming, particularly as the reformer scale is increased. Hot spots can damage the catalyst and cold spots can decrease the catalytic activity: an uniform temperature distribution through the reaction is very important. To this purpose, recently, metallic and ceramic foam catalysts (a porous metal inside which many pores are formed) with high thermal conductivity, uniform thermal dispersion, and high mechanical strength are widely studied. These catalyst supports, then, are increasing the heat and mass transfer. Also the reticulated structure of foam materials cell provides high activity for unit volume. Open or closed cells can be presented in the structure of the foam $[37,38]$. Closed cell-type foam has pores that are not interconnected, while the open cell-type foam has pores that are interconnected, so a fluid can pass easily through the cells.

As a catalyst support, metallic foams (e.g., $\mathrm{Cu}$ ) have good heat transfer capability, better mixing of reactant gases, reduced pressure drop in the reactor, low density, high thermal conductivity, but low thermal shock limitations [39]. Ceramic foams (e.g., SiC, SSiC), with high mechanical strength and thermal conductivity $[40,41]$, are in general used in reactors with molten salts [42, 43, 44]. Instead, open cell-type metallic foams are widely used forother industrial processes as carbon dioxide reforming, Fisher-Tropshc synthesis, catalytic combustion of methane and methane steam reforming $[31,44,45,46]$.

In literature several works are about the kinetics and reaction mechanism of steam reforming and several reactions have to be considered for a proper description of the process [47]. According the $\mathrm{Xu}$ and Froment kinetic the reactions of carbon intermediates with adsorbed oxygen are the rate determining steps. However, the model is very complex and other researches follow the work of $\mathrm{Xu}$ and Froment proposing their own mechanism for the simplified kinetic model of this reaction [48] as the Numaguchi kinetic [27].

Studies about design and rating of membrane reactors are present in literature $[1,45,49,50]$. The operation of natural gas reformer is related to its structure parameters, operating conditions, heat transfer: it is an important aspect in the design of steam reforming reactor.

Few works are present in literature about the simulation of integrated membrane reactor for hydrogen production: except for Sarvar-Amini et al. [51] and Ye et al. [52]regarding a fluidized bed membrane reactor, all models are solved in Fortran, Matlab or other computers programs $[53,54]$. But a model developed in Aspen for the integrated membrane reactor using foam catalyst supports for hydrogen production from natural gas steam reforming is not present.

In this research a rating for natural gas steam reforming is carried out founding the correct heat transfer coefficient of the reactor. It is the first integrated membrane reactor in Europe at pilot plant that use a ceramic foam catalyst as support, to produce hydrogen by natural gas steam reforming. A simulation is modeled in Aspen Plus software using the correlations presented in literature for the catalyst foam, Sieverts' law and Numaguchi kinetic. 
Material balances and permeation of hydrogen through membrane are solved with this software: the model predictions on reactor performance show satisfactory agreement with experimental results.

Future works should optimize the operation of the integrated membrane reactor to ensure a higher hydrogen production.

\section{MATERIALS AND METHODS}

\subsection{Description and Modeling of the Integrated}

\section{Membrane Reactor}

The configuration of the integrated membrane reactor is shown in Fig. 1: an external steel tube as shell is present with an inner membrane tube where steam used as sweep gas flows to subtract the permeate hydrogen from the reaction zone. The system allows to produce hydrogen with high purity, increasing the conversion despite the relatively low operating temperatures. Methane, in natural gas, and steam are continuously feeded into the reaction zone at a molar ratio of steam to carbon $(\mathrm{S} / \mathrm{C})$ equal to $1: 3$; steam is used as sweep gas improving the performance of the process. The maximum temperature of the process is equal to $809 \mathrm{~K}$, while the maximum pressure is equal to 10 atmand a $\mathrm{Ni}(10) / \mathrm{CeLaZr}$ catalyst supported on $\mathrm{SSiC}$ ceramic foam with open cells is used to improve the reaction.

The heat is externally exchanged by utilizing molten salts, as the binary mixture of $\mathrm{NaNO}_{3} / \mathrm{KNO}_{3}(60 / 40 \% \mathrm{w} / \mathrm{w})$ called "solar salts", due to the use of solar energy. This innovative system allows the mismatch between the fluctuating solar source and the operation of the process. Table 1 and 2 show the data about the integrated membrane reactor and its measures respectively.

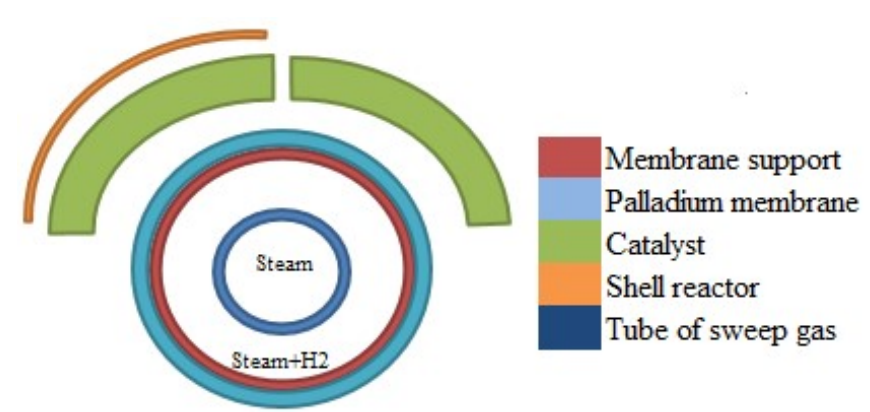

Fig-1 Section of the integrated membrane reactor

Table 1: Dimensions of the integrated membrane reactor

\begin{tabular}{lcc}
\cline { 2 - 3 } & $\begin{array}{c}\text { Internal } \\
\text { diameter } \\
(\mathrm{mm})\end{array}$ & $\begin{array}{c}\text { External } \\
\text { diameter } \\
(\mathrm{mm})\end{array}$ \\
\hline Membrane support & 10 & 14 \\
Palladium membrane & n.a. & n.a. \\
Catalyst & 16 & 40 \\
Shell reactor & 42.7 & 48.3 \\
Tube of sweep gas & 6 & 9 \\
\hline
\end{tabular}

Table 2: Data about the integrated membrane reactor

\begin{tabular}{lrl}
\hline Number of tubes & 10 \\
Length/Diameter & 48.39 \\
Length of tube & $748 \mathrm{~mm}$ \\
Number of tube series & 1 \\
GHSV & $384 \mathrm{~h}^{-1}$ \\
Number of baffle & 10 \\
Length of membrane & $748 \mathrm{~mm}$ \\
Area of membrane & $0.57 \mathrm{~m}^{2}$ \\
Volume of catalyst & $9.5 \mathrm{l}^{1}$ \\
\hline
\end{tabular}

A Gibbs reactor is used to model the integrated membrane reactor in Aspen Plus software, as shown in Fig. 2, while a code in Fortran sub-routine is build and integrated into the software to simulate the permeation and separation of hydrogen through the membrane inside the reactor, as described by the Sievert's law. In the Gibbs reactor model, Gibbs free energy minimization is performed to determine the product composition. During the simulation, the reactor is divided into multi plug flow sub-reactors, reaching the thermodynamic equilibrium locally. It is a one dimensional model: in the multi plug flow reactors the gas composition only varies in the vertical direction with negligible axial dispersion. The temperature is not uniform inside the reactor: gas and molten salt change the temperature along the reactor length. Also the co-existence of $\mathrm{H}_{2} \mathrm{O}, \mathrm{CO}, \mathrm{CO}_{2}$, $\mathrm{CH}_{4}$ is neglected on membrane separation. The membrane permeability for the simulation is set to $20 \mathrm{Nm}^{3}$ bar $^{0.5}$. Soave RedlickKwong (SRK) thermodynamic model is set to model the integrated membrane reactor and to have the material and energy balances. Pressure drops are neglected in the calculations: the pressure in both sides of membrane is kept at constant. Steady-state operation is assumed during the simulations.

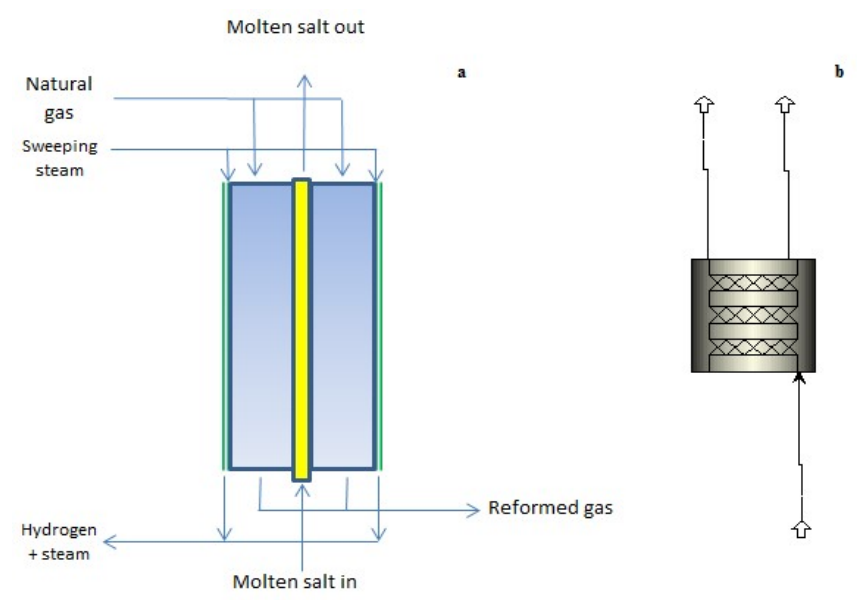

Fig-2 a) Scheme of the integrated membrane reactor; b) Scheme of the integrated membrane reactor in Aspen Plus environment

\subsection{NUMAGUCHI KINETIC REACTION}

The reactions that are involved in the natural gas steam reforming or known as methane steam reforming are the endothermic steam reforming reactions and the exothermic water-gas swift reaction according the following system (See eq. 1-3): 


$$
\begin{aligned}
& \mathrm{CH}_{4}+\mathrm{H}_{2} \mathrm{O} \leftrightarrow \mathrm{CO}+3 \cdot \mathrm{H}_{2} \\
& \mathrm{CO}+\mathrm{H}_{2} \mathrm{O} \leftrightarrow \mathrm{CO}_{2}+\mathrm{H}_{2} \\
& \mathrm{CH}_{4}+2 \cdot \mathrm{H}_{2} \mathrm{O} \leftrightarrow \mathrm{CO}_{2}+4 \cdot \mathrm{H}_{2}
\end{aligned}
$$

The reaction enthalpy is respectively equal to $206,-41,165$ $\mathrm{kJ} / \mathrm{mol}$ and the overall products are $\mathrm{CO}, \mathrm{CO}_{2}$ and $\mathrm{H}_{2}$. A mixture of $\mathrm{H}_{2}$ and $\mathrm{CO}$ is produced, the next processing is required to convert $\mathrm{CO}$ to $\mathrm{CO}_{2}$ used the water gas swift, then to remove the $\mathrm{CO}_{2}$ and other impurities. The third reaction is a linear combination of other reactions. The kinetic rate of the system is described by the hybrid equation of LangmuirHinshelwood according a power law, assuming that the surface reaction is the rate-determining step. In the expressions, $\alpha$ and $\beta$ are the parameters for the adsorption term according the Freundlich adsorption rate, while $\mathrm{m}$ is the number of adsorption sites included in the rate (See eq. 4-5).

$$
\begin{aligned}
& r_{r f} \\
& =k_{R}{ }^{o} \cdot \exp \left(-\frac{E_{p}}{R \cdot T}\right) \\
& \cdot \frac{k_{r} \cdot\left(P_{C H 4} \cdot P_{H 2 O}-P_{C O} \cdot \frac{P_{H 2}^{3}}{k_{P}}\right)}{\left(P_{C H 4}^{\alpha_{R}} \cdot P_{H 2 O}^{\beta_{R}}\right) \cdot\left(1+\sum_{k=1}^{k} K_{k} \cdot P_{k}\right)^{m}} \\
& k_{r}=k_{R}{ }^{o} \cdot \exp \left(-\frac{E_{p}}{R \cdot T}\right)
\end{aligned}
$$

In methane steam reforming, the adsorption equilibrium constant for steam is larger respect to other components. For this reason, the rate of the reactions according the Numaguchi kinetic are obtained [55] (See eq. 6-7):

$$
\begin{aligned}
r_{r f}=k_{R}{ }^{o} \cdot \exp \left(-\frac{E_{p}}{R \cdot T}\right) \cdot \frac{\left(P_{C H 4}-P_{C H 4(e q)}\right)}{\left(P_{C H 4}^{\alpha_{R}} \cdot P_{H 2 O}^{\delta_{R}}\right)} \\
r_{s f}=k_{S}{ }^{o} \cdot \exp \left(-\frac{E_{p}}{R \cdot T}\right) \\
\cdot \frac{\left(P_{C O}-P_{C O(e q)}\right)}{\left(P_{C H 4}^{\alpha_{S}} \cdot P_{H 2 O}^{\delta_{S}}\right)}
\end{aligned}
$$

where $r_{r f}$ is for the steam reforming reaction, $r_{s f}$ is for the shift reaction, $\mathrm{P}_{\mathrm{CH} 4(\mathrm{eq})}$ and $\mathrm{P}_{\mathrm{CO}(\mathrm{eq})}$ are the pressures at equilibrium conditions and $\mathrm{R}$ the constant of universal gas. Table 3 shows the values of parameters inside the reactions [55]:

Table 3: Values of parameters for Numaguchi kinetics

\begin{tabular}{cr}
$\mathrm{k}_{\mathrm{R}}^{\mathrm{o}}$ & $92 \cdot 10^{8}$ \\
$\mathrm{E}_{\mathrm{R}}$ & $106.87 \mathrm{~kJ} / \mathrm{mol}$ \\
$\alpha_{\mathrm{R}}$ & 0 \\
$\delta_{\mathrm{R}}$ & 0.596 \\
$\mathrm{k}_{\mathrm{S}}^{\mathrm{o}}$ & $8.688 \cdot 10^{5}$ \\
$\mathrm{Es}$ & $54.531 \mathrm{~kJ} / \mathrm{mol}$ \\
$\alpha_{\mathrm{S}}$ & 0 \\
$\delta_{\mathrm{S}}$ & 0 \\
\hline
\end{tabular}

\subsection{HEAT AND MATERIAL BALANCES OF THE PROCESS}

The mass balance in the gaseous phase is given for each component by the expression (See eq. 8):

$$
\frac{d F_{i}}{d z}=\rho \cdot \Omega \cdot \sum_{j=1}^{N_{R}=3} v_{i j} \cdot r_{j} \cdot \eta_{j}
$$

For the methane and the carbon dioxide, result (See eq. 9$10)$ :

$$
\begin{aligned}
& \frac{d F_{C H 4}}{d z}=\rho \cdot \Omega \cdot\left(-r_{1} \cdot \eta_{1}-r_{3} \cdot \eta_{3}\right) \\
& \frac{d F_{C O 2}}{d z}=\rho \cdot \Omega \cdot\left(+r_{2} \cdot \eta_{2}+r_{3} \cdot \eta_{3}\right)
\end{aligned}
$$

where $\Omega$ is the reactor section, $\rho$ is the catalyst density, $\eta_{1}$, $\eta_{2}, \eta_{3}$ are the effectiveness factors. The hydrogen flow rate through the membrane is expressed by the following relationship (See eq. 11):

$$
\frac{d F_{H 2, p e r m}}{d z}=J_{H 2} \cdot 2 \cdot \pi \cdot\left(r_{\circ}+\delta\right)
$$

with $\mathrm{r}^{\mathrm{o}}$ is the inner radius, $\delta$ the thickness of the membrane, $\mathrm{J}_{\mathrm{H} 2}$ the hydrogen permeation through the palladium membrane according the Sieverts' law as a function of the difference in the square root of hydrogen partial pressures on both sides of the membrane [56] (See eq. 12):

$$
J_{H 2}=\frac{Q_{p d}}{\delta} \cdot\left(P_{H 2, r}^{0.5}-P_{H 2, p}^{0.5}\right)
$$

where $\delta$ is the membrane thickness, $\mathrm{Q}_{\mathrm{pd}}$ the permeation of hydrogen, $\mathrm{P}_{\mathrm{H} 2, \mathrm{r}}$ and $\mathrm{P}_{\mathrm{H} 2, \mathrm{p}}$ the hydrogen pressure in permeate and reaction side. The energy balance is described below (See eq. 13):

$$
\begin{gathered}
\rho_{g} \cdot C_{p, g} \cdot \frac{\partial T}{\partial z}=\rho_{s} \cdot(1-\varepsilon) \cdot \sum_{j=1}^{3}\left(-\Delta H_{j}\right) \cdot r_{j}-\frac{U \cdot \pi \cdot D}{A} \\
\cdot\left(T-T_{w}\right)
\end{gathered}
$$

where $T_{W}$ is the temperature of the outer reactor wall, $D$ is the outer reactor diameter, $U$ the heat transfer coefficient between the outer wall and the reacting/separating zone, $\rho_{g}$ and $\rho_{\mathrm{s}}$ the density of gas and salt respectively, $\mathrm{C}_{\mathrm{pg}}$ and $\mathrm{C}_{\mathrm{ps}}$ respectively the heat capacity of gas and salt, A the section flow rate, $\varepsilon$ the void fraction. The assumptions, reported in table 4, are considered for the gas properties, foam catalyst and molten salts, while Fig. 3 shows the foam catalyst support used in the integrated membrane reactor. 


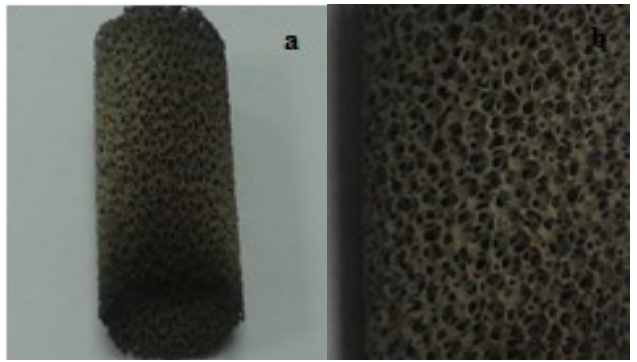

Fig-3a) Images of SSiC-foam coated with $\mathrm{Ni}(10) / \mathrm{CeLaZr}$ catalyst; b)Stereomicroscopic image of SSiC-foam coated with $\mathrm{Ni}(10) / \mathrm{CeLaZr}$ catalyst

Table 4: Properties of gas, catalytic foam, molten salt

\begin{tabular}{|c|c|c|}
\hline \multicolumn{3}{|c|}{ Properties of gas } \\
\hline Conductivity at inlet of reactor & 0.09756 & $\mathrm{~W} / \mathrm{mK}$ \\
\hline Conductivity at outlet of reactor & 0.13232 & $\mathrm{~W} / \mathrm{mK}$ \\
\hline Conductivity average & 0.11494 & $\mathrm{~W} / \mathrm{mK}$ \\
\hline Viscosity at inlet of reactor & 0.00003 & Pas \\
\hline Viscosity at outlet of reactor & 0.00003 & Pas \\
\hline Viscosity average & 0.00003 & Pas \\
\hline Heat capacity at inlet of reactor & 2145 & $\mathrm{~J} / \mathrm{kgK}$ \\
\hline Heat capacity at outlet of reactor & 3063 & $\mathrm{~J} / \mathrm{kgK}$ \\
\hline Heat capacity average & 2604 & $\mathrm{~J} / \mathrm{kgK}$ \\
\hline Density at inlet of reactor & 2.827 & $\mathrm{~kg} / \mathrm{m}^{3}$ \\
\hline Density at outlet of reactor & 2.405 & $\mathrm{~kg} / \mathrm{m}^{3}$ \\
\hline Density average & 2.616 & $\mathrm{~kg} / \mathrm{m}^{3}$ \\
\hline \multicolumn{3}{|c|}{ Properties of foam catalyst support } \\
\hline Porosity & 15 & ppi \\
\hline Degree of vacuum & 0.83 & \\
\hline Pore diameter & 0.001693 & $\mathrm{~m}$ \\
\hline $\mathrm{d}$ & 0.000268 & $\mathrm{~m}$ \\
\hline Cell size & 15753 & $\mathrm{~m}$ \\
\hline Fiber diameter & 0.000272 & $\mathrm{~m}$ \\
\hline \multicolumn{3}{|c|}{ Properties of molten salt } \\
\hline Heat capacity & 0.37 & $\mathrm{kcal} / \mathrm{kgK}$ \\
\hline Density & 1742 & $\mathrm{~kg} / \mathrm{m}^{3}$ \\
\hline Viscosity & 4.32 & $\mathrm{~kg} / \mathrm{mh}$ \\
\hline Flow rate & 800 & $\mathrm{~kg} / \mathrm{h}$ \\
\hline Section of flow rate & 0.017 & $\mathrm{~m}^{2}$ \\
\hline Velocity & 0.008 & $\mathrm{~m} / \mathrm{s}$ \\
\hline
\end{tabular}

\section{RESULTS AND DISCUSSIONS}

3.1 CALCULATION OF THE HEAT TRANSFER COEFFICIENTS

To have a correct model of the integrated membrane reactor, the heat transfer coefficients for gas, molten salt and the global heat coefficient are calculated as reported in table 5. The heat transfer coefficient of gas is calculated according the correlationsof foam reported by Lu et al. [57]. Infect in general, two different models can be used to describe the heat transfer in a porous medium: the one-equation equilibrium model or the two-equation non-equilibrium model [58]. Temperatures of molten salts at the inlet and outlet of the reactor are set equal to $823 \mathrm{~K}$ and $817 \mathrm{~K}$ respectively. The temperatures of natural gas at inlet and outlet are equal to $798 \mathrm{~K}$ and $809 \mathrm{~K}$ for retentate and 723 for permeate respectively while the duty of reactor is set to $1870 \mathrm{kcal} / \mathrm{h}$.

Table 5: Heat transfer parameters of the integrated membrane reactor calculated in rating mode

\begin{tabular}{lr} 
Reynoldof salt & 1631 \\
Prandtlof salt & 3.37 \\
Nusseltof salt & 13.90 \\
Prandtlof gas & 0.64 \\
Reynold of gas & 1.04 \\
Heat transfercoefficient of gas & $278 \mathrm{kcal} / \mathrm{hm}^{2} \mathrm{~K}$ \\
Heat transfercoefficient of salt & $142 \mathrm{kcal} / \mathrm{h} \mathrm{m}^{2} \mathrm{~K}$ \\
Global heat transfer coefficient & $90 \mathrm{kcal} / \mathrm{hm}^{2} \mathrm{~K}$ \\
\hline
\end{tabular}

\subsection{RESULTS OF SIMULATION AND SENSITIVITY ANALYSIS}

A modeling of the integrated membrane reactor is carried out with Aspen Plus software, comparing the obtained results with experimental data. Also a rating mode is developed to verify the heat capacity of the system, using the previous found parameters for the heat transfer.

Infect, therating mode uses these results as input to simulate the reactor with the kinetic expression. Physical data are update in the model of the integrated membrane reactor. Comparing the values of hydrogen partial pressure, as in Fig. 4, it is evident that the model implemented in Aspen Plusis correct. In particular, Fig. 4 shows thehydrogen partial pressure in the retentate and permeate side of the integrated membrane reactor versus the reactor length.In addition, the reactor can exchange the imposed duty, so the verification is satisfied.

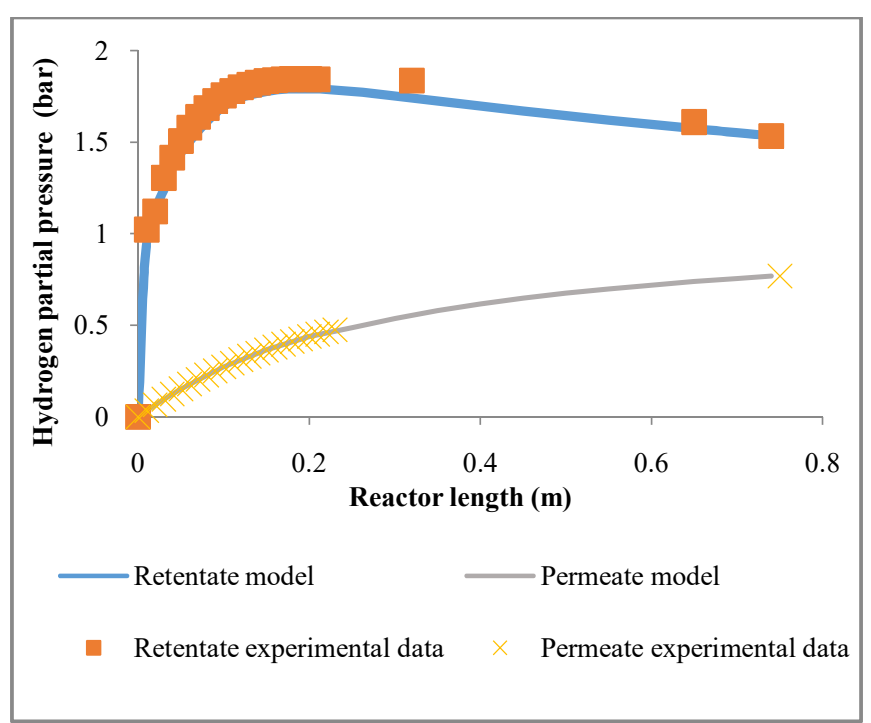

Fig-4 Hydrogen partial pressure in the retentate and permeate side of the integrated membrane reactor (data model: continuous line; experimental data: points) 
Table 6 reports the heat and material balances of the process obtained by the simulation in Aspen Plus.

Table 6: Material and energy balances of the integrated membrane reactor obtained by the simulation in Aspen Plus

Feed Retentate Permeate

\section{Composition (\%w/w)}

\begin{tabular}{lccc} 
Methane & 0.1917 & 0.1136 & 0 \\
Hydrogen & 0.1114 & 0.1243 & 0.551 \\
Carbon dioxide & 0.0517 & 0.1896 & 0 \\
Carbon monoxide & 0.0042 & 0.0116 & 0 \\
Water & 0.6409 & 0.5609 & 0.499 \\
Nitrogen & 0 & 0 & 0 \\
Ethane & 0 & 0 & 0 \\
Propane & 0 & 0 & 0 \\
I-butane & 0 & 0 & 0 \\
N-butane & 0 & 0 & 0 \\
I-pentane & 0 & 0 & 0 \\
N-pentane & 0 & 0 & 0 \\
Helium & 0 & 0 & 0 \\
& & & \\
Total flow rate $(\mathrm{kmol} / \mathrm{h})$ & 0.2629 & 0.2068 & 0.196 \\
Density $\left(\mathrm{kg} / \mathrm{m}^{3}\right)$ & 2.604 & 3.113 & 0.241 \\
Temperature $(\mathrm{K})$ & 798 & 809 & 723 \\
Pressure $(\mathrm{barg})$ & 9 & 9 & 0.65 \\
Enthalpy $(\mathrm{cal} / \mathrm{mol})$ & -43439 & -21981 & -45218 \\
\hline
\end{tabular}

The total flow rate at the inlet of the reactor is equal to $0.2629 \mathrm{kmol} / \mathrm{h}$ : the methane composition is equal to 0.1917 $\% \mathrm{w} / \mathrm{w}$ so the value of $\mathrm{S} / \mathrm{C}$ is equal to 3.3 . In the feed there is $0.1114 \% \mathrm{w} / \mathrm{w}$ of hydrogen: upstream of the integrated membrane reactor, a reactor for natural gas steam reforming with a membrane stage at the downstream is present. The permeate stream of this membrane reactor is the feed for the integrated membrane reactor. For this reason, hydrocarbons as propane, butane, pentane are not present in the feed: they are removed in the previous stages. Table 6 shows that the composition of hydrogen in the permeate stream is equal to $0.55 \% \mathrm{w} / \mathrm{w}$ : to improve the recovery of hydrogen and so to have a higher hydrogen mole fraction in the permeate a higher membrane permeability can be used, as shown in the sensitivity analysis.

In the retentate stream $\mathrm{CO}_{2}$ and $\mathrm{H}_{2} \mathrm{O}$ are the main products, while $\mathrm{CO}, \mathrm{H}_{2}, \mathrm{CH}_{4}$ are the secondary products. The temperature of gases in the retentate is equal to $809 \mathrm{~K}$, a higher value of temperature respect to feed and permeate respectively equal to $798 \mathrm{~K}$ and $723 \mathrm{~K}$. Also, $0.088 \mathrm{kmol} / \mathrm{h}$ of steam are send to the reactor as sweep gas.

The methane conversion is equal to $61 \%$. A sensitivity analysis is carried out to study the process: the effect of membrane permeability is analyzed for methane conversion, rector temperature, partial pressure of hydrogen, hydrogen recovery versus the reactor length.
Fig. 5 shows the methane conversion as a function of reactor length and membrane permeability. Methane conversion increases faster near the inlet of the reactor, but decrease along the length: an equilibrium between the changes of reaction rate and variations of species concentration is achieved [59]. It is evident that the methane and water consumption rate and carbon dioxide production rate are higher near the inlet of the reactor, because the mixture is not in equilibrium [60]. The membrane permeability has a positive effect on methane conversion but this effect is not linear at high methane conversion due to the mass transfer limitations inside the reactor. Methane conversion reaches a value of $60 \%$ for lower value of permeability but it can assume a value of $90 \%$ at higher value of permeability.

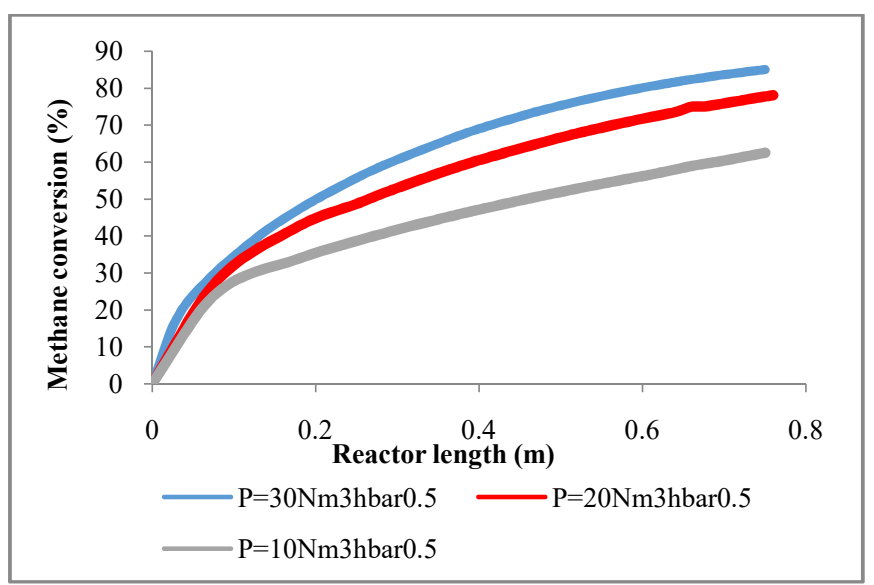

Fig-5 Methane conversion versus membrane length and membrane permeability

The reaction temperature has an important role in the reactor performance, because influences the thermodynamic and kinetic: with the increase of the temperature, the hydrogen permeation rate through the membrane and the reaction rate also increase, producing a higher methane conversion and hydrogen recovery [61]. Fig. 6 shows a cold spot at the inlet of the reactor, while the endothermic behavior of the methane reforming determines a reduction of the temperature in the remaining length. After $0.1 \mathrm{~m}$ of the reactor length, the system seems to be isothermal with temperature near to $810 \mathrm{~K} \mathrm{[62].} \mathrm{In} \mathrm{the} \mathrm{initial} \mathrm{portion} \mathrm{of} \mathrm{the}$ reactor, the temperature decreases strongly due to the large amount of converted methane: the net balance of the reaction is strongly endothermic. After the minimum temperature, the gas is heated (the heat that is transferred from the membrane tube is higher than the heat consumed by the reaction), while after the middle of the reactor the thermodynamic equilibrium is achieved. The membrane permeability has a negative effect on temperature, however, the permeability has a mild effect on the maximum temperature enabling the satisfaction of the membrane operating requirements. The use of foam support improves the heat transfer inside the reactor, resulting in a lower mean temperature difference between the region near the wall and the region near the membrane. Moreover, the maximum temperature drop that occurs near the inlet of the reactor is significantly smaller, an important parameter in order to protect and prolong the lifetime of the Pd-based membrane. 


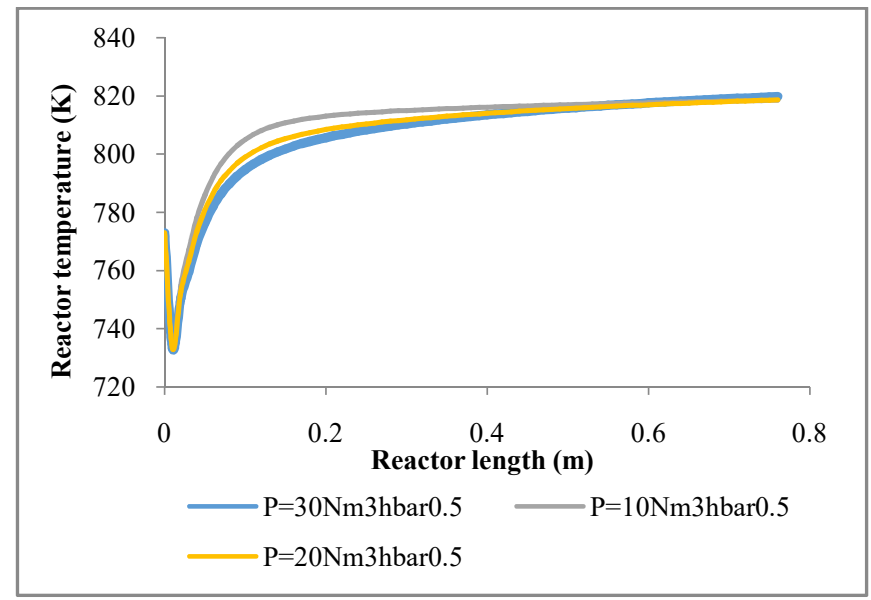

Fig-6 Temperature of reactor versus reactor length and membrane permeability

It is interesting to study the hydrogen partial pressure along the reactor, as shown in Fig. 7. The trend reaches a maximum, while after the separation through the membrane the hydrogen partial pressure decreases. Comparing Fig.5 and 7 , the methane conversion increases with the decreasing of hydrogen partial pressure. In the same conditions the hydrogen recovery will increase.

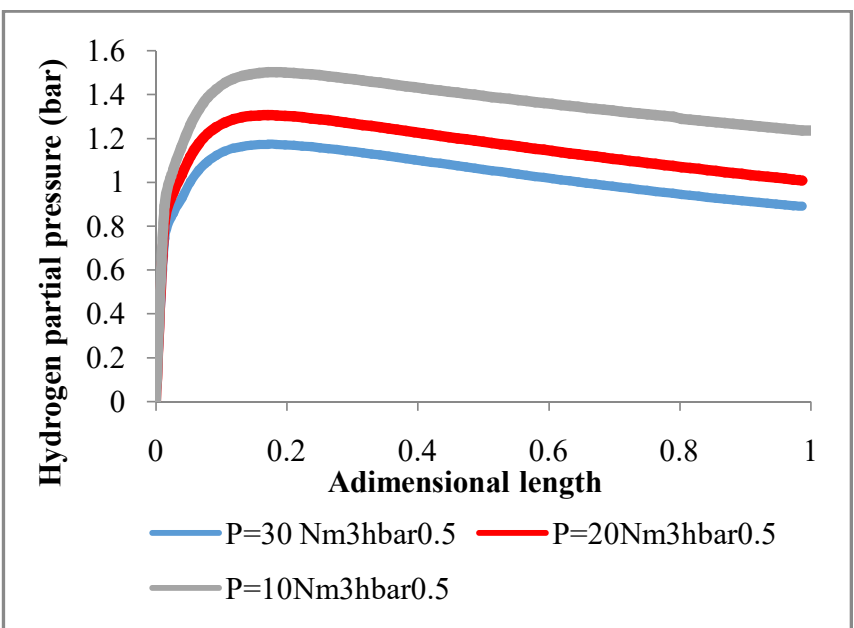

Fig-7 Hydrogen partial pressure versus adimensional length of the reactor and membrane permeability

Fig. 8 shows the hydrogen recovery defined as the ratio of the permeated hydrogen to the total amount of hydrogen generated by the reaction.

The graph shows that a back permeation is present at the inlet of the reactor due to the permeation of hydrogen before that the gas enters in the reaction zone. After the reaction zone, the hydrogen recovery reaches its maximum value at the maximum driving force(the difference in partial pressure of hydrogen between reaction side and permeation side).As the magnitude of the driving force decreases, the hydrogen recovery decreases too. Infect, when the temperature decreases, according the thermodynamic equilibrium the amount of formed hydrogen is smaller: the reactions proceed towards the consumption of hydrogen, instead to its formation. Fig. 8 shows that the membrane permeability has a positive effect on hydrogen recovery. The positive effect is higher at higher value of permeability. At $30 \mathrm{Nm}^{3} \mathrm{hbar}^{0.5}$ the maximum value of hydrogen recovery is equal to $93 \%$. Hydrogen permeation rates can be further enhanced by the increased membrane surface area.

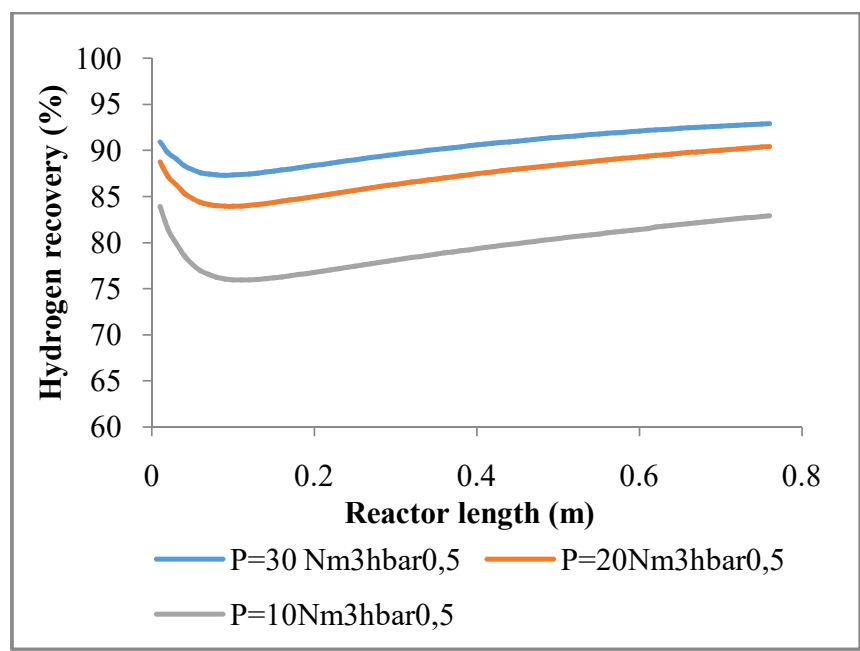

Fig-8 Hydrogen recovery versus reactor length and membrane permeability

In addition to membrane permeability, pressure has a positive effect on methane conversion and hydrogen recovery. When the pressure increases, both methane conversion and hydrogen recovery increase: a high reaction pressure increases the driving force for the products, especially for hydrogen recovery resulting in an enhancement of the methane conversion [63].

\section{CONCLUSIONS}

Natural gas steam reforming to produce hydrogen in an integrated membrane reactor is studied from a modeling point of view using Aspen Plus simulator.

Catalyst supported on ceramic SSiC foam coated with $\mathrm{Ni}(10) / \mathrm{CeLaZr}$ is used to ensure an uniform temperature distribution. The correct heat transfer coefficients are found by adequate foam correlations and rating procedure. Material and energy balances are imposed considering that molten salts are used to exchange heat from solar energy. Numaguchi kinetic is used to describe the process.

The mathematical model developed in Aspen Plus shows a good agreement with the experimental data, obtained by the integrated reactor at pilot plant scale. The methane conversion obtained from the simulation is equal to $61 \%$ with $0.55 \% \mathrm{w} / \mathrm{w}$ of hydrogen in the permeate stream. A sensitivity study of methane conversion, hydrogen recovery, temperature of reactor, hydrogen partial pressure versus reactor length and membrane permeability is performed.

Results suggest that permeability of membrane has positive effect on methane conversion and hydrogen recovery. For the other parameters the effect is negative.

\section{ACKNOWLEDGEMENT}

The author of the study would like to thank the European Commission for funding this work. 


\section{REFERENCES}

[1] H. Butcher, C.J.E. Quenzel, L. Breziner, J. Mettes, B.A. Wilhite, P. Bossard, Design of an annular microchannel reactor (AMR) for hydrogen and/or syngas production via methane steam reforming. International Journal of Hydrogen Energy. 39 (2014) 18046-18057.

[2] W. Yu, T. Ohmoria, S. Kataokaa, T. Yamamotoa, A. Endoa, M. Nakaiwaa, N. Itoh, A comparative simulation study of methane steam reforming in a porous ceramic membrane reactor using nitrogen and steam as sweep gases. International Journal of Hydrogen Energy. 33 (2008) 685692.

[3] D. Dasa, T.N. Veziroglu, Advances in biological hydrogen production processes. International Journal of Hydrogen Energy. 33 (2008) 6046-57.

[4] B.C.R. Ewan, R.W.K. Allen, A figure of merit assessment of the routes to hydrogen. International Journal of Hydrogen Energy. 30 (2005) 809-19.

[5] R.Y. Chein, Y.C. Chen, Y. Sheng Lin, J.N. Chung, Experimental study on the hydrogen production of integrated methanol-steam reforming reactors for PEM fuel cells. International Journal of Thermal Sciences. 50 (2011) 1253-1262.

[6] M. Farsi, DME production in multi-stage radial flow spherical membrane reactors: Reactor design and modeling. Journal of Natural Gas Science and Engineering. 20 (2014) 366-372.

[7] J. Tong, Y. Matsumura, Pure hydrogen production by methane steam reforming with hydrogen-permeable membrane reactor. Catalysis Today. 111 (2006) 147-152.

[8] M. Saric, Y.C. van Delft, R. Sumbharaju, D.F. Meyer, A. de Groot, Steam reforming of methane in a bench-scale membrane reactor at realistic working conditions. Catalysis Today. 193 (2012) 74-80.

[9] B. Bej, N.C. Pradhan, S. Neogi, Production of hydrogen by steam reforming of methane over alumina supported nano-NiO/ $\mathrm{SiO}_{2}$ catalyst. Catal. Today. 207 (2013) 28-35.

[10] H.W.A. El Hawa, S.N. Paglieri, C.C. Morris, A. Harale, J.D. Way, Application of a $\mathrm{Pd}-\mathrm{Ru}$ composite membrane to hydrogen production in a high temperature membrane reactor. Sep. Purif. Technol. 147 (2015) 388-397.

[11] Y.-M. Lin, S.-L. Liu, C.-H. Chuang, Y.-T. Chu, Effect of incipient removal ofhydrogen through palladium membrane on the conversion of methane steamreforming: experimental and modeling, Catal. Today 82 (2003) 127139.

[12] J. Tong, Y. Matsumura, H. Suda, K. Haraya, Experimental study of steam reforming of methane in a thin $(6 \mu \mathrm{m})$ Pd-based membrane reactor, Ind. Eng. Chem. Res. 44 (2005) 1454-1465.

[13] M. De Falco, G. Iaquaniello, A. Salladini, Experimental tests on steam reforming of natural gas in a reformer and membrane modules, (RMM) plant. Journal of Membrane Science. 368 (1-2) (2011a) 264-274.

[14] F. Borgognoni, S. Tosti, M. Vadrucci, A. Santucci, Pure hydrogen production in a $\mathrm{Pd}-\mathrm{Ag}$ multi-membranes module by methane steam reforming. Int. J. Hydrogen Energy. 36 (2011) 7550-7558.
[15] M. De Falco, D. Barba, S. Cosenza, G. Iaquaniello, L. Marrelli, Reformer and membrane modules plant powered by a nuclear reactor or by a solar heated molten salts: Assessment of the design variables and production cost evaluation. International Journal of Hydrogen Energy. 33 (20) (2008) 5326-5334.

[16] D.S.A. Simakov and M. Sheintuch, Experimental optimization of an autonomous scaled-down methane membrane reformer for hydrogen generation. Industrial and Engineering Chemistry Research. 49 (3) (2010) 1123-1129.

[17] A. Giaconia, L. Turchetti, G. Monteleone, B. Morico, G. Iaquaniello, K. Shabtai, et al. Development of a solar powered, fuel-flexible compact steam reformer: theCoMETHy Project. ChemEng Trans. 35 (2013) 433-8.

[18] M.D. Falco, V. Piemonte, Solar enriched methane production by steam reforming process: reactor design. Int $\mathrm{J}$ Hydrogen Energy. 36 (2011) 7759-62.

[19] A.S. Augustine, Y.H. Ma, N.K. Kazantzis, High pressure palladium membrane reactor for the high temperature wateregas shift reaction. International Journal of Hydrogen Energy. 36 (2011) 5350-60.

[20] R. Sanz, J.A. Calles, D. Alique, L. Furones, S. Ordonez, P. Marın, et al. Preparation, testing and modelling of a hydrogen selective $\mathrm{Pd} / \mathrm{YSZ} / \mathrm{SS}$ composite membrane. International Journal of Hydrogen Energy. 36157 (2011) 83-93.

[21] M. Sheintuch, D.S.A. Simakov, Alkanes dehydrogenation. In: Falco MD, Marrelli L, Iaquaniello G, editors. Membrane reactors for hydrogen production processes. New York: Springer-Verlag London Limited (2011) 183-200.

[22] S. Yun, S.T. Oyama, Correlations in palladium membranes for hydrogen separation: a review. J Memb Sci. 375 (2011) 28-45.

[23] S. Hao, D.S. Sholl, Computational prediction of durable amorphous metal membranes for $\mathrm{H}_{2}$ purification. J. Membr. Sci. 381 (1-2) (2011) 192-196.

[24] E. Ozdogan, J. Wilcox, Investigation of $\mathrm{H}_{2}$ and $\mathrm{H}_{2} \mathrm{~S}$ adsorption on niobium-and copper-doped palladium surfaces. J. Phys. Chem. B. 114 (40) (2010) 12851-12858.

[25] C.G. Sonwane, J. Wilcox, Y.H. Ma, Solubility of hydrogen in $\mathrm{Pd} / \mathrm{Ag}$ and $\mathrm{Pd} / \mathrm{Au}$ binary alloys using density functional theory. J. Phys. Chem. B. 110 (48) (2006) 2454924558.

[26] J. Tong, L. Su, K. Haraya, H. Suda, Thin and defectfree Pd-based composite membrane without any interlayer and substrate penetration by a combined organic and inorganic process. Chem. Commun. (2006) 1142-1144.

[27] S. Tosti, L. Bettinali, S. Castelli, F. Sarto, S. Scaglione, V. Violante, Sputtered, electroless, and rolledpalladiumceramicmembranes. J. Membr. Sci. 196 (2002) 241-9.

[28] G. Leonzio, Mathematical modeling of integrated membrane reactor for methane steam reforming. International of hydrogen energy. International Journal of Research in Engineering and Technology. 5 (10) (2016), 10.15623/ijret.2016.0510043

[29] B. Anzelmo, J. Wilcox, S. Liguori, Natural gas steam reforming reaction at low temperature and pressure conditions for hydrogen production via Pd/PSS membrane reactor. Journal of Membrane Science. 522 (2017) 343-350. 
[30] P. Ferreira-Aparicioa, M. Benitoa, K. Kouachib, S. Menad, Catalysis in membrane reformers: a highperformance catalytic system for hydrogen production from methane. Journal of Catalysis 231 (2005) 331-343.

[31] J.T. Richardson, M. Garrait, J.K. Hung, Carbon dioxide reforming with $\mathrm{Rh}$ and $\mathrm{Pt}-\mathrm{Re}$ catalysts dispersed on ceramic foam supports. Applied Catalysis A: General. 225 (2003) 69-82.

[32] N. Gokon, Y. Osawa, D. Nakazawa, T. Kodama, Kinetics of $\mathrm{CO}_{2}$ reforming of methane by catalytically activatedmetallic foam absorber for solar receiver-reactors. International Journal of Hydrogen Energy. 34 (2009) 17871800 .

[33] L. Giani, C. Cristiani, G. Groppi, E. Tronconi, Washcoating method for $\mathrm{Pd} / \gamma-\mathrm{Al}_{2} \mathrm{O}_{3}$ deposition on metallic foams, Applied Catalysis B: Environmental. 62 (2006) 121131.

[34] K. Sutthiumporn, T. Maneerung, Y. Kathiraser, S. Kawi, $\mathrm{CO}_{2}$ dry-reforming of methane over $\mathrm{La0}$.8Sr0.2Ni0.8M0.2O3 perovskite $(\mathrm{M}=\mathrm{Bi}, \mathrm{Co}, \mathrm{Cr}, \mathrm{Cu}$, $\mathrm{Fe}$ ): roles of lattice oxygen on $\mathrm{C}-\mathrm{H}$ activation and carbon suppression. International Journal of Hydrogen Energy. 37 (2012) 11195-11207.

[35] A. Iulianelli, G. Manzolini, M. De Falco, S. Campanari, T. Longo, S. Liguori, A. Basile, $\mathrm{H}_{2}$ production by low pressure methane steam reforming in a Pd-Ag membrane reactor over a Ni-based catalyst: Experimental and modeling. International Journal of Hydrogen Energy. 35 (2010) 11514-11524.

[36] D. Li, R. Li, M. Lu, X. Lin, Y. Zhan, L. Jiang, Carbon dioxide reforming of methane over $\mathrm{Ru}$ catalysts supported on Mg-Al oxides: A highly disperse and stable $\mathrm{Ru} / \mathrm{Mg}(\mathrm{Al}) \mathrm{O}$ catalyst. Applied Catalysis B: Environmental 200 (2017) 566-577.

[37] H.-F. Chang, W.-J. Pai, Y.-J. Chen, W.-H. Lin, Autothermal reforming of methane for producing highpurity hydrogen in a $\mathrm{Pd} / \mathrm{Ag}$ membrane reactor. International Journal of Hydrogen energy. 35 (2010) 12986-12992.

[38] C.Y. Zhao, Review on thermal transport in high porosity cellular metal foams with open cells. International Journal of Heat and Mass Transfer. 55 (2012) 3618-3632.

[39] P.J. Tan, S.R. Reid, J.J. Harrigan, Z. Zou, S. Li, Dynamic compressive strength properties of aluminum foams, Part I - experimental data and observations. Journal of the Mechanics and Physics of Solids. 53 (2005) 21742205.

[40] P. S. Roy, N.-K. Park, K. Kim, Metal foam-supported $\mathrm{Pd}-\mathrm{Rh}$ catalyst for steam methane reforming and its application to SOFC fuel processing. International Journal of Hydrogen Energy. 39 (2014) 4299-4310.

[41] N. Gokon, Y. Yamawaki, D. Nakazawa, T. Kodama, $\mathrm{Ni} / \mathrm{MgO}-\mathrm{Al}_{2} \mathrm{O}_{3}$ and $\mathrm{Ni}-\mathrm{Mg}-\mathrm{O}$ catalyzedSiC foam absorbers for high temperature solar reforming of methane. Int. J. Hydrogen Energy. 35 (2010) 7441-7453.

[42] H. Liu, S. Li, S. Zhang, J. Wang, G. Zhou, L. Chen, X. Wang, Catalytic performance of novel $\mathrm{Ni}$ catalysts supported on $\mathrm{SiC}$ monolithic foam in carbon dioxide reforming of methane to synthesis gas. Catal. Commun 9 (2008) 51-54.
[43] J. Qi, Y. Sunb, Z. Xiec, M. Collins, H. Dua, T. Xiong, Development of $\mathrm{Cu}$ foam-based Ni catalyst for solar thermal reforming of methane with carbon dioxide. Journal of Energy Chemistry. 24 (2015) 786-793.

[44] M. Patrascu, M. Sheintuch, On-site pure hydrogen production by methane steam reforming in high flux membrane reactor: Experimental validation, model predictions and membrane inhibition. Chemical Engineering Journal. 262 (2015) 862-874.

[45] H. Roh, D. Lee, K. Koo, U. Jung, W. Yoon, Natural gas steam reforming for hydrogen production over metal monolith catalyst with efficient heat-transfer. Int. J. Hydrogen Energy 35 (2010) 1613-1619.

[46] L. Sang, B. Sun, H. Tan, C. Du, Y. Wu, C. Ma, Catalytic reforming of methane with $\mathrm{CO}_{2}$ over metal foam based monolithic catalysts. International Journal of Hydrogen Energy. 37 (2012) 13037-13043.

[47] A. Olivieri and F. Vegliò, Process simulation of natural gas steam reforming: Fuel distribution optimization in the furnace. Fuel processing technology. 89 (2008) 622-632

[48] A.K. Avetisova, J.R. Rostrup-Nielsen, V.L. Kuchaeva, J.H. BakHansenb, A.G. Zyskina, E.N. Shapatina, Steadystate kinetics and mechanism of methane reforming with steam and carbon dioxide over $\mathrm{Ni}$ catalyst. Journal of Molecular Catalysis A: Chemical. 315 (2010) 155-62

[49] E. Kertalli, M.F. Neirad'Angelo, J.C. Schouten, T.A. Nijhuis, Design and optimization of a catalytic membrane reactor for the direct synthesis of propylene oxide. Chemical Engineering Science. 138 (2015) 465-472.

[50] F.V. Vazquez, P. Simell, J. Pennanen, J. Lehtonen, Reactor design and catalysts testing for hydrogen production by methanol steam reforming for fuel cells applications. International Journal of Hydrogen Energy. 41 (2016) 924935.

[51] A. Sarvar-Amini, R. Sotudeh-Ghrebagh, H. Bashiri, N. Mostoufi, A. Haghtalab, Sequential simulation of fluized bed membrane reactor for the steam methane reforming using Aspen Plus. Energy Fuels. 21 (2007) 3593-3598.

[52] G.Y. Ye, D.L. Xie, W.Y. Qiao, J.R. Grace, C.J. Lim, Modeling of fluidized bed membrane reactors for hydrogen production from steam methane reforming with aspen plus. International Journal of Hydrogen Energy. 34 (2009) 47554762 .

[53] A. Alamdari, Performance assessment of packed bed reactor and catalytic membrane reactor for steam reforming of methane through metal foam catalyst support. Journal of Natural Gas Science and Engineering. 27 (2015) 934-944.

[54] Z.B. Rui, Y.D. Li, Y.S. Lin, Analysis of oxygen permeation through dense ceramic membranes with chemical reaction of finite rate. Chemical Engineering Science. 64 (2009) 172-179.

[55] B.A. Finlayson, Nonlinear analysis in chemical engineering, McGraw-Hill (1980) 60-171.

[56] G. Barbieri, A. Brunetti, G. Tricoli, E. Drioli, An innovative configuration of a Pd-based membrane reactor for the production of pure hydrogen. Experimental analysis of water gas shift, J. PowerSources. 182 (2008) 160-167.

[57] W. Lu, C.Y. Zhao. Thermal analysis on metal-foam filled heat exchangers. Part I: Metal-foam filled pipes, Int. J. Heat Mass Transfer. 49 (2006) 2751-2761. 
[58] A. Bejan, Convection Heat Transfer, second ed., Wiley, New York, 1995.

[59] A.S. Kyriakides, D. Ipsakis, S. Voutetakisa, S. Papadopouloua, P. Seferlis, Modelling and Simulation of a Membrane Reactor for the Low Temperature Methane Steam Reforming. Chemical engineering transactions. 35 (2013).

[60] A.S. Kyriakides, L. Rodrıguez-Garcıa, S. Voutetakis, D. Ipsakis, P. Seferlis, S. Papadopoulou, Enhancement of pure hydrogen production through the use of a membrane reactor. International Journal of Hydrogen Energy. 39 (2014) 4749-4760

[61] L. Chibane and B. Djellouli, Methane Steam Reforming Reaction Behaviour in a Packed Bed Membrane Reactor. International Journal of Chemical Engineering and Applications. 2, 3 (2011).

[62] F. Wang, B. Qi, G. Wang, L. Li, Methane steam reforming: kinetics and modeling over coating catalyst in microchannel reactor. Int J Hydrog Energy. 38 (2013) 5693704.

[63] W. Yu, T. Ohmori, T. Yamamoto, A. Endo, M. Nakaiwa, T. Hayakawa, N. Itoh, Simulation of porous ceramic membrane reactor for hydrogen production. Int. J. Hydrogen Energy. 30 (2005) 1071-1079.

\section{BIOGRAPHIES}

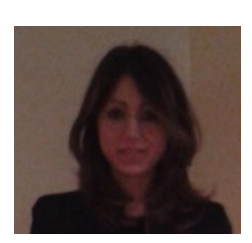

Grazia Leonzio is a $\mathrm{PhD}$ student at Department of Industrial and Information Engineering and Economics, University of L'Aquila, Via Giovanni Gronchi 18, 67100 L'Aquila, Italy; email: grazia.leonzio@graduate.univaq.it; 